\title{
Identifying key criteria in development of Industrial Engineering education
}

\author{
Tomasz Nitkiewicz ${ }^{1,}$, and Zuhal Ayen ${ }^{2}$ \\ ${ }^{1}$ Częstochowa University of Technology, Faculty of Management, 42200 Częstochowa, Poland \\ ${ }^{2}$ Sakraya University, Production Engineering Department, Sakraya, Turkey
}

\begin{abstract}
The objective of this study is to define criteria in current development of Industrial Engineering (IE) education on the basis of studies and concepts published in commonly accessible databases and knowledge exchange platforms. General assumption of the study is that the universal criteria used in developing IE study programs are already defined and some experiences on their use are already published. The expected outcome of the study is to identify the criteria that could support the development of curriculum for MSc in IE. The approach used here is content analysis with the publication related to the higher level education in the field of Industrial Engineering.
\end{abstract}

\section{Introduction}

The concept of Industry 4.0 is rapidly entering into many areas of economic processes and societal life. Certainly, it is an ongoing process already, especially, when industrial processes are considered, but also, it is a catchword to cover all the technological changes that enter to the society through new products, services and new ways they are offered and serviced. The problem that we want to address is the readiness of the higher education system to support Industry 4.0 challenge. For a start, we choose to take a close look at the development directions of Industrial Engineering Master Programs that should be, basically, preparing new adapts of Industry 4.0 practices. The scope of the study is defined within the project titled „Curriculum Development of Master's Degree Program in Industrial Engineering for Thailand Sustainable Smart Industry (MSIE4.0)" and its output is geographically limited to Thailand but opening phase addresses the global context of IE education that should face the challenge of Industry 4.0.

In short, Industry 4.0 concept could be defined as: "technical integration of cyberphysical systems into manufacturing and logistics and the use of the Internet of Things and Services in industrial processes" [1]. It will influence significantly working environments as a whole, addressing its purchase, production, manufacturing, sales or maintenance processes by including concepts as smart manufacturing and maintenance, with high degree of automation and integration in all enterprise processes [2]. Moreover, it will increase the role and the participation of customers in all the life cycle phases, starting from Design by customer approach [3].

* Corresponding author: tomasz.nitkiewicz@,wz.pcz.pl 


\section{Methodology}

In order to find appropriate resources documenting the approaches to development of Industrial Engineering education and indicating critical issues in the process we have used the simplest possible keywords: "industrial engineering" and "education". Basic search gave us numerous resources and most of them were not relating exactly to IE education and need further narrowing and filtering. Our primal search could be narrowed by some additional keywords in order to filter the results to the ones addressing the issue of our interest. The filtering phrases used are:

- "Management and Production Engineering"

-"Manufacturing Engineering"

-“Quality Management”

- "Product Management"

-"Master of Science (MSc)"

-"Studying Program"

In addition, we used the resources that were published in 2010 or later. The database we have used at first is Science Direct database, and it gave us most of the results used here. We have also added some additional resources from another databases (Scopus, Springer and Emerald). Automatic filtering has limited the resources to several thousands of articles, and we have manually searched through about 250 entries altogether in order to get the final set of resources. Manual filtering was based on removing the sources that were not referring to IE education on higher level, or to too detailed issues. Since the goal of the paper is to identify the major criteria for IE programs development we stopped the publication review process. But the process could be continued for the purposes of numerical analysis and referring the development criteria to the geographical, industrial, academic or cultural specificity of countries and regions addressed. Finally, we left 25 resources for our further analysis.

\section{Defining the criteria for development of IE programs}

Basing on the scope of the publications the following issues are identified as framework for basic criteria for IE education development:

- General program

- Educational methods and tools

- Cooperation and networks

- Industry based training

- Competences and skills

- Quality assurance and accreditation

The issues identified as possible framework for development criteria are overlapping and, usually, are coming together in order to get more holistic approach to IE programs development. It is worth to notice that most of the issues raised in the publications fall into "General program" category, but we limit it to the issues that address IE program as a whole. Distinction between the categories of "Cooperation and networks" and "Industry based training" could be also difficult since the trainings come from the cooperation and perhaps networking solutions between academia and industry. We have decided to single out the category of "Industry based training" since it is very strongly represented issue in publications. On the other hand, we decided to leave also category of "Cooperation and networks" since it could be just an organizational approach towards industrial training but also cooperation with other actors in the surroundings of IE university, like other universities, public authorities, R\&D sector or just its graduates. 
Table 1. Description of development criteria for IE programs.

\begin{tabular}{|c|c|}
\hline Criteria & Description \\
\hline General program & $\begin{array}{c}\text { Sustainable value creation [4]; outcome-based education structure [5-9]; } \\
\text { cooperative and participative education [10] }\end{array}$ \\
\hline Methods and Tools & $\begin{array}{c}\text { Experimental and problem based learning [11-13]; Interactive tools [14- } \\
17] ; \text { sustainability assessment tools [4], participative education [4,7] }\end{array}$ \\
\hline $\begin{array}{c}\text { Cooperation and } \\
\text { networks }\end{array}$ & $\begin{array}{c}\text { Cooperative and participative education [4,7,18], incorporation of } \\
\text { international exchange [8]; experience sharing [18,19] }\end{array}$ \\
\hline $\begin{array}{c}\text { Industry based training } \\
\text { Competences and skills }\end{array}$ & $\begin{array}{c}\text { Cooperative training [7,10,19]; industrial talks and visits [7,18]; industry } \\
\text { pulled MSc theses and projects [6,13,20]; evaluation of competences and } \\
\text { skills [2,6,21,22] }\end{array}$ \\
\hline $\begin{array}{c}\text { Industry-based evaluation [10,23]; soft skills (p.e. communication and } \\
\text { language) [2]; ICT and software skills [14,15]; managing innovation } \\
\text { skills [13,22,24] }\end{array}$ \\
\hline $\begin{array}{c}\text { Quality assurance and } \\
\text { accreditation }\end{array}$ & $\begin{array}{c}\text { Benchmarking of accreditation and quality assurance systems [8,25,26]; } \\
\text { certifying and adapting QMS [26,27] }\end{array}$ \\
\hline
\end{tabular}

\section{Conclusions}

The set of identified criteria is a first step towards the development of IE curriculum that will provide graduates ready for Industry 4.0 challenges. The criteria should be used in development but also in the process of adopting IE curricula to the changing environment. It is important to notice that the criteria should be also adopted to the local conditions of implementing universities. This would include the references to the national higher education system, national and regional industry specificity, market development trends, candidates and students preferences and predispositions, possible external financing options or educational offer of a university. Finally, it is important to mention that development and adoption of any university curriculum, including IE programs, is an ongoing process and it constantly demands attention, intervention, work, sources and goodwill to make it a successful story of universities facing the challenge of Industry 4.0.

\section{Acknowledgements}

This publication is a partial outcome of project „Curriculum Development of Master’s Degree Program in Industrial Engineering for Thailand Sustainable Smart Industry (MSIE4.0)" that has been funded with support from the European Commission (Project Number: 586137-EPP-1-2017-1-TH-EPPKA2-CBHE-JP). Co-funded by the

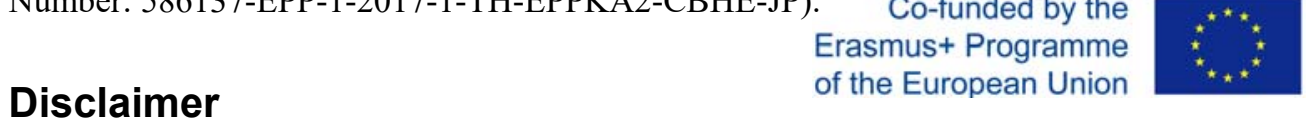

This publication reflects the views only of the authors, and the Commission cannot be held responsible for any use which may be made of the information contained therein.

\section{References}

1. W. Wahlster, J. Helbig, A. Hellinger, M. A. V. Stumpf, J. Blasco, H. Galloway, and H. Gestaltung, Securing the future of German manufacturing industry. Recommendations for implementing the strategic initiative INDUSTRIE 4.0. Final report of the Industrie 4.0 Working Group (2013) 
2. L. Prifti, M. Knigge, H. Kienegger, and H. Krcmar, A Competency Model for 'Industrie 4.0' Employees, in Proceedings der 13. Internationalen Tagung Wirtschaftsinformatik, 46-60 (WI, 2017)

3. Risdiyono and P. Koomsap, J Intell Manuf, 24, 295-311 (2013)

4. P. Bilge, F. Badurdeen, and I. S. Jawahir, Procedia CIRP, 40, 516-523 (2016)

5. O. Akir, T. H. Eng, and S. Malie, Procedia - Soc. Behav. Sci., 62, 87-92 (2012)

6. D. Mesquita, R. M. Lima, M. A. Flores, C. Marinho-Araujo, and M. Rabelo, Int. J. Ind. Eng. Manag., 6, 3, 121-131 (2015)

7. R. Nordin, A. A. A. Bakar, N. Zainal, and H. Husain, Procedia - Soc. Behav. Sci., 60, 271-276 (2012)

8. A. Samer Ezeldin, Z. Omar, R. M. Yasin, R. Hamid, N. M. Tawil, K. Yusoff, and M. S. Rasul, Procedia - Soc. Behav. Sci., 102, 267-275 (2013)

9. Z. Sari, Procedia - Soc. Behav. Sci., 102, 560-567 (2013)

10. N. Brahimi, F. Dweiri, I. Al-Syouf, and S. A. Khan, Procedia - Soc. Behav. Sci., 102, 446-453 (2013)

11. R. M. Lima, D. Mesquita, M. Amorim, G. Jonker, and M. A. Flores, Int. J. Ind. Eng. Manag., 3, 2, 75-82 (2012)

12. R. Riedel, D. Jentsch, S. Tröger, and E. Müller, Integrating experiential learning into Industrial Engineering curricula - a case study, IFAC Proc., 43, 326-330 (2010)

13. B. Abaza, I. Paraschiv, M. Spiroiu, and C. Stanciu, Project-Based Pedagogy For A New Product Development, in INTED2015 Proceedings (2015)

14. J. W. Volkmann, M. Landherr, D. Lucke, M. Sacco, M. Lickefett, and E. Westkämper, Procedia CIRP, 41, 632-637 (2016)

15. A. Miller and M. Bures, New Approach to Industrial Engineering Education with the Help of Interactive Tools, Procedia - Soc. Behav. Sci., 174, pp. 3413-3419, (2015)

16. D. Jelonek, The Development of Software Agents in e-Learning 3.0, in ICIT 2015 The 7 th International Conference on Information Technology (2015)

17. P. Maresca, E. Gómez, J. Caja, C. Barajas, and R. Ledesma, Procedia Eng., 132, $205-$ $212(2015)$

18. N. Jamaluddin, A. Ayob, S. A. Osman, N. T. Kofli, and S. Johar, Procedia - Soc. Behav. Sci., 102, 648-653 (2013)

19. A. Ayob, S. A. Osman, M. Z. Omar, N. Jamaluddin, N. T. Kofli, and S. Johar, Procedia - Soc. Behav. Sci., 102, 48-54 (2013)

20. S. Fernandes, D. Mesquita, M. A. Flores, and R. M. Lima, Eur. J. Eng. Educ., 39, 1, 55-67 (2014)

21. R. M. Lima, P. H. Andersson, and E. Saalman, , Eur. J. Eng. Educ., 42, 1, 1-4,(2017)

22. M. Palma, I. de los Ríos, and D. Guerrero, Procedia - Soc. Behav. Sci., 46, 15701580, (2012)

23. M. San-Juan, M. D. P. De Tiedra, O. Martín, F. J. Santos, R. López, R. Suárez, and R. Mahillo-Isla, Procedia Eng., 132, 221-227 (2015)

24. R. M. Lima, D. Mesquita, C. Rocha, M. Rabelo, R. M. Lima, D. Mesquita, C. Rocha, and M. Rabelo, Production, 27 (2017)

25. M. A. L. Domingo, J. A. Albajez, and J. Santolaria, Procedia Eng., 63, 786-795 (2013)

26. H. Chowdhury, F. Alam, S. K. Biswas, M. T. Islam, and A. K. M. S. Islam, Quality Assurance and Accreditation of Engineering Education in Bangladesh, Procedia Eng., 56, pp. 864-869, Jan. (2013)

27. R. Ulewicz, System Approach To Assure Quality of Education At the Faculty of Management of Czestochowa University of Technology., Polish J. Manag. Stud., 8, pp. 259-268, (2013) 